\title{
There are too many medical physics journals!
}

\author{
Martin Caon ${ }^{1}$
}

Published online: 22 September 2016

(C) Australasian College of Physical Scientists and Engineers in Medicine 2016

What I really mean is that there are too many unscientific "scientific journals". There must be. Why else do I get so many spam emails requesting that my esteemed person make a valuable contribution to their Journal(s) which publish in fields that I have no expertise in? Why else, if not the existence of too much capacity, would journals need to beg for content from potential authors who demonstrably have no knowledge of the Journal's field (unless of course, they want authors to pay for publication)? There are so many that I will restrict the discussion below to the Medical Physics journals_-even though I have not yet been spammed by a Medical Physics journal.

I define a Medical Physics journal as one that has the term "medical physics" (not necessarily in English) in the title, or has both the words "physics" (or "physical") and "medical" (or "biomedical" or "medicine") in the title, or as one whose website states that they publish "medical physics" articles (for example the "Red Journal", BPEX, R\&EB, RPT, IJRR). However the three journals: Physiological Chemistry and Physics and Medical NMR; Magnetic Resonance Materials in Physics, Biology, and Medicine; EPJ Nonlinear Biomedical Physics (est. 2013)— which may or may not have supplanted the now ceased BioMed Central published Nonlinear Biomedical Physics (est. 2007)—and medical journals with the term "physical medicine" in their title, were not considered to be Medical Physics journals. Any appropriate journal published by a national association of medical physicists qualifies for inclusion. I know that it could be argued that nuclear

Martin Caon

martin.caon@flinders.edu.au

1 Flinders University School of Health Sciences, Adelaide, SA, Australia medicine, health physics, biomedical engineering, radiation protection, dosimetry, medical imaging, radiology, oncology, biophysics and other areas of scientific endeavour overlap with medical physics. Well argue away, but I have drawn the line as above.

Strangely, "medical physics" is not a term that is used to describe a subject area or subject category by Scimago Journal Ranking or by Thomson Reuters Journal Citation Reports or used by them to classify scientific journals. Hence the term is not applied by those organisations to any of the Journals that I have identified.

As far as I can ascertain there are 32 Medical Physics journals (or journals that publish medical physics articles) and a further two that have ceased to publish (Table 1). All of them have websites and post their tables of contents and abstracts online, and this is how I found them. Ten of the journals publish articles in a language that is not English. Be advised that the publishers of three of the listed journals feature on Jeffrey Beall's list of predatory publishers [1]. Prior to 1980 there were 5 Medical Physics journals (including this one). By 1990 there were 8 , by 2000 there were 14 and by 2010 the number had risen to 24 . Ten more have established since then. It is clear that the number of medical physics journals, the frequency of their issues and the number of published medical physics articles has been increasing [2]. And that the rate of increase has been increasing. This is not surprising as the number of medical physicists has risen in response to the development of new radiotherapy treatments and the introduction of new diagnostic equipment and the introduction of modern medicine into developing countries [3]. In turn these developments have been driven by the research efforts of the equipment manufacturers and the users of the new equipment and by medical physics students/registrars completing their 
Table 1 Medical physics journal titles, their year of commencing publication and their sponsoring societies

\begin{tabular}{|c|c|c|c|}
\hline Title & Volume 1 & Country & Sponsor/publisher \\
\hline Physics in Medicine and Biology & 1956 & UK & Institute of Physics and Engineering in Medicine \\
\hline $\begin{array}{l}\text { Radiation and Environmental Biophysics (formerly } \\
\text { Biophysik prior to 1974) }\end{array}$ & 1963 & Germany & Springer \\
\hline Medical Physics & 1974 & USA, Canada & $\begin{array}{l}\text { American Association of Physicists in Medicine } \\
\text { Canadian Organization of Medical Physicists }\end{array}$ \\
\hline Medical Engineering and Physics & 1976 & UK & Institute of Physics and Engineering in Medicine \\
\hline $\begin{array}{l}\text { Australasian Physical \& Engineering Sciences in } \\
\text { Medicine (preceded by Australasian Bulletin of } \\
\text { Medical Physics and Biophysics 1966-1976) }\end{array}$ & 1977 & $\begin{array}{l}\text { Australia, New } \\
\text { Zealand }\end{array}$ & $\begin{array}{l}\text { Australasian College of Physical Scientists and } \\
\text { Engineers in Medicine Asia-Oceania Federation of } \\
\text { Organizations for Medical Physics }\end{array}$ \\
\hline $\begin{array}{l}\text { Japanese Journal of Medical Physics (Igaku butsuri) } \\
\text { (formerly Japan Radiological Physics) (Non- } \\
\text { English) }\end{array}$ & 1981 & Japan & Japanese Society of Medical Physics \\
\hline Chinese Journal of Medical Physics (Non-English) & 1984 & China & Chinese Society of Medical Physics \\
\hline $\begin{array}{l}\text { Physica Medica (European Journal of Medical } \\
\text { Physics) }\end{array}$ & 1986 & Italy, Ireland, France & $\begin{array}{l}\text { Associazione Italiana di Fisica Medica, the } \\
\text { European Federation of Organisations for Medical } \\
\text { Physics Irish Association of Physicists in } \\
\text { Medicine, and; the Société Française de Physique } \\
\text { Médicale }\end{array}$ \\
\hline $\begin{array}{l}\text { Zeitschrift für Medizinische Physik (Journal of } \\
\text { Medical Physics) }\end{array}$ & 1990 & $\begin{array}{l}\text { Germany, Austria, } \\
\text { Switzerland }\end{array}$ & $\begin{array}{l}\text { German and Austrian Society of Medical Physic and } \\
\text { the Swiss Society of Radiobiology and Medical } \\
\text { Physics }\end{array}$ \\
\hline $\begin{array}{l}\text { Progress in Medical Physics (formerly Korean } \\
\text { Journal of Medical Physics) Non-English }\end{array}$ & 1990 & Korea & Korean Society of Medical Physics \\
\hline $\begin{array}{l}\text { Journal of Medical Physics (AMPI Medical Physics } \\
\text { Bulletin till 1994) }\end{array}$ & 1994 & India & Association of Medical Physicists of India \\
\hline $\begin{array}{l}\text { Polish Journal of Medical Physics and Engineering } \\
\text { (Non-English) }\end{array}$ & 1995 & Poland & Polish Society of Medical Physics \\
\hline Meditsinskaya Fizika (Non-English) & 1995 & Russia & Association of Medical Physicists in Russia \\
\hline Revista de Fisica Medica (Non-English) & 1999 & Spain & Sociedad Española de Física Médica \\
\hline Journal of Applied Clinical Medical Physics & 2000 & $\begin{array}{l}\text { USA, } \\
\text { Canada }\end{array}$ & $\begin{array}{l}\text { American Association of Physicists in Medicine } \\
\text { Canadian Organization of Medical Physicists }\end{array}$ \\
\hline $\begin{array}{l}\text { Revista de Bioingeniería y Física Médica Cubana } \\
\text { (Non-English) }\end{array}$ & 2000 & Cuba & $\begin{array}{l}\text { Sociedad Cubana de Bioingeniería, and Instituto } \\
\text { Central de Investigacion Digital }\end{array}$ \\
\hline BMC Medical Physics & 2001 & & (Ceased 2014) Bio Med Central \\
\hline $\begin{array}{l}\text { International Journal of Radiation Research } \\
\text { (formerly Iranian J of Radiation Research) }\end{array}$ & 2003 & Iran & Novin Medical Radiation Institute \\
\hline Iranian Journal of Medical Physics & 2004 & Iran & Iranian Association of Medical Physicists \\
\hline Biomedical Imaging \& Intervention Journal & 2005 & Malaya & $\begin{array}{l}\text { (ceased 2012) Department of Biomedical Imaging } \\
\text { (Radiology) Faculty of Medicine, University of } \\
\text { Malaya }\end{array}$ \\
\hline Revista Brasileira de Física Médica (Non-English) & 2007 & Brazil & Associação Brasileira de Física Médica \\
\hline Bangladesh Journal of Medical Physics & 2008 & Bangladesh & Bangladesh Medical Physics Association \\
\hline Radiological Physics and Technology & 2008 & Japan & $\begin{array}{l}\text { Japanese Society of Radiological Technology and } \\
\text { Japan Society of Medical Physics }\end{array}$ \\
\hline $\begin{array}{l}\text { African Journal of Medical Physics, Biomedical } \\
\text { Engineering and Sciences }\end{array}$ & 2009 & Nigeria, Africa & $\begin{array}{l}\text { Journal of African Union of Biomedical Engineering } \\
\text { and Sciences }\end{array}$ \\
\hline Journal of Biomedical Physics and Engineering & 2011 & Iran & Shiraz University of Medical Sciences \\
\hline $\begin{array}{l}\text { International Journal of Medical Physics, Clinical } \\
\text { Engineering and Radiation Oncology }\end{array}$ & 2012 & & Scientific Research Publishing (on Beall's list) \\
\hline Revista de Fizica Medicala (Non-English) & 2013 & Romania & $\begin{array}{l}\text { Colegiul Fizicienilor Medicali din Romania } \\
\text { (College of Physicists in Medicine in Romania) }\end{array}$ \\
\hline Medical Physics International & 2013 & & IOMP \\
\hline Journal of Medical Physics and Biophysics & 2014 & Indonesia & Indonesian Association of Physicists in Medicine \\
\hline
\end{tabular}


Table 1 continued

\begin{tabular}{llll}
\hline Title & Volume 1 & Country & Sponsor/publisher \\
\hline Biomedical Physics \& Engineering Express & 2015 & UK & $\begin{array}{c}\text { IOP (endorsed by Institute of Physics and } \\
\text { Engineering in Medicine }\end{array}$ \\
$\begin{array}{l}\text { Revista Latinoamericana de Fisica Medica (some) } \\
\quad 2015\end{array}$ & Latin America & Asociación Latinoamericana de Física Medica \\
$\begin{array}{l}\text { Non-English } \\
\text { Insights in Medical Physics }\end{array}$ & 2016 & & Insight Medical Publishing (on Beall's list) \\
International Medical Physics Journal & 2016 & Journal Network (on Beall's list) \\
Physics in Medicine & 2016 & & Elsevier (open access) \\
\hline
\end{tabular}

professional qualification. The pressure to publish the outcomes of this research is irresistible.

It appears that if a journal is published on behalf of the Association, College, Institute, Organisation, Society, Union or Federation of medical physicists from a particular nation (or group of nations) that the journal is legitimately scientific and has the appropriate standing within the scientific community. These journals were established by scientific societies to meet the genuine scientific need to communicate the findings of research to identified groups of scientific specialists. Meeting such needs is what a scientific society is supposed to do. In turn, submitted manuscripts are scrutinised by scientific specialists and improved by their comments. Such peers are willing to review a manuscript within their expertise because that is what members of a scientific society do. The sponsoring society provides the journal with editorial direction and peer review effort and hence credibility, durability and a ready source of manuscripts. Most of the journals in Table 1 are so sponsored. Keeping abreast of the expansion of knowledge in medical physics is of benefit to the professional physicist and a well-informed employee is of benefit to their employer as well. Consequently the employer usually is happy for the medical physicist to provide honorary editorial and reviewing support to a journal "for the public good" and indeed often expects them to provide the manuscripts as well. Nevertheless, many reviewers decline invitations to review a manuscript saying that they are too busy. Perhaps they get too many requests because there are too many journals.

A recent development is the establishment of for-profit journals by for-profit publishing houses that can be legitimate or otherwise. The development of the internet has removed almost all barriers to the communication of research findings. Publishing issues and articles electronically on the internet has allowed journals to avoid the expense of producing and mailing hardcopies of their issues and (perhaps) freed them from the need to be spawned and nurtured by scientific societies. I say "perhaps" because in 2016 three journals that are unsupported by national medical physics societies have announced their arrival via their websites. It remains to be seen who will submit manuscripts and what will be published within them. While established and successful journals provide a substantial stream of revenue to their sponsoring societies, the profit is put towards running the societies and pursuing their aims. It also remains to be seen whether reviewers will be willing to work pro bono for companies whose intent is to profit from their efforts and from the manuscripts submitted to them, when the profits are not directed towards a scientific society.

By suggesting that there are too many Medical Physics journals I am not advocating that some should shut down. However to paraphrase Garfield's Law, it is possible to provide adequate coverage of all medical physics with only a relatively small number of journals. It could be argued that the cessation of publication of two of them since 2012 is evidence that indeed there are too many Medical Physics journals. Perhaps there were too few manuscripts submitted to sustain them, or perhaps authors chose not to submit to those journals. The number of manuscripts submitted to APESM has increased steadily since 2009 so there seems to be no shortage of submitted medical physics (and biomedical) manuscripts. However as APESM accepts only about $30 \%$ of submitted manuscripts for publication there is a much smaller number of manuscripts that are scientifically defendable and that report novel findings. Hence the increased number of submitted manuscripts alone is not a sufficient reason for the increase in the number of Medical Physics journals.

On the other hand, Table 1 lists five new journals that have commenced publication in 2015, 2016 indicating that their publishers believe there may be too few! Given that the capacity for medical physics papers in the journal market place continues to increase, I await the spam.

\section{References}

1. Beall J (2016) https://scholarlyoa.com/publishers/. Accessed 19 July 2016 
2. Caon M (2013) Operational statistics for the APESM journal (Jan 2012-Feb 2013) australas. Phys Eng Sci Med 36(1):5-7. doi:10. 1007/s13246-013-0189-x

3. Round WH, Jafari S, Kron T, Azhari HA, Chhom S, Hu Y, Mauldon GF, Cheung KY, Kuppusamy T, Pawiro SA, Lubis LE, Soejoko DS, Haryanto F, Endo M, Han Y, Suh TS, Ng KH,
Luvsan-Ish A, Maung SO, Chaurasia PP, Jafri SMA, Farrukh S, Peralta A, Toh HJ, Sarasanandarajah S, Shiau AC, Krisanachinda A, Suriyapee S, Vinijsorn S, Nguyen TC (2015) Brief histories of medical physics in Asia-Oceania. Australas Phys Eng Sci Med 38(3):381-398. doi:10.1007/s13246-015-0342-9 